Bangladesh J. Zool. 41(2): 207-215, 2013

\title{
MORPHOMETRY OF INDIAN ROOFED TURTLE, PANGSHURA TECTA (GRAY 1831) IN BANGLADESH
}

\author{
Md. Lokman Hossain ${ }^{1}$, Shorab Uddin Sarker and Noor Jahan Sarker \\ Department of Zoology, Faculty of Biological Sciences, University of Dhaka, \\ Dhaka-1000, Bangladesh
}

\begin{abstract}
Morphometric study was conducted on Indian roofed turtle, Pangshura tecta, between January 1997 and December 2000 in several district of Bangladesh. The mean weight of adult male was $92.6 \pm 13.3 \mathrm{~g}$ and of female 441.1 $\pm 185.4 \mathrm{~g}$. The length and width of carapace as well as those of the plastron and the height of the shell varied with the body weight of the turtle. The percentage of hard parts of the body weight of $P$. tecta was $35.8 \pm 2.5 \%$, whereas percentage of soft parts of the body weight was $64.2 \pm 2.5 \%$. The average weight of the female $P$. tecta was 4.8 times higher than that of the male.
\end{abstract}

Key words: Morphometry, Indian roofed turtle, Pangshura tecta

\section{INTRODUCTION}

Turtles have long been associated with human either in myths, as food sources, as ornaments or as traditional medical ingredient (Rashid and Khan, 2000). The wetlands of Bangladesh are rich in Chelonian fauna that can contribute to ecological balance and control water quality (Hossain and Sarker, 1995a). Major species of freshwater turtles control the growth of aquatic weeds and other floating vegetation, and maintain healthy aquatic environment for wildlife and fish (Philip et al., 1998). Freshwater turtles perform a valuable ecological service as scavengers in the tanks, rivers and stagnant water and thus keep the aquatic ecosystems free from pollution (Rao and Singh1987).

Scientists like Boulenger (1890), Chaudhury (1912), Shafi and Quddus (1987), Khan (1980, 1982 \& 1987), Fugler (1984), Barua and Islam (1986), Gupta (1987), Rashid and Swingland (1997), Rao and Singh (1987 and 1990), Rashid (1991), Hossain and Sarker (1993 and 1995a,b), Sarker and Hossain (1997) and Hossain (2000) worked on some ecological aspects of freshwater turtles of Bangladesh. Whitaker and Andrews (1997), Vogt and Benitez (1997) and Rhodin (2001) worked on morphometry, ecology, breeding biology and trend of trade of the selected freshwater turtles in different countries.

The situation of Asian chelonians is put into risk by habitat destruction (Collins 1990). In consideration of low reproductive rate of most species they are decreased drastically from natural habitat (Sandra and Daniela 2000). The Government of Bangladesh has decided to protect turtle and formulated some

${ }^{1}$ Corresponding author: Department of Zoology, Dhaka College, Dhaka, Dhanmondi, Dhaka-1205, Bangladesh. E-mail: drlokmanhossain@yahoo.com 
rules to establish turtle nurseries and hatcheries. Some of the turtles may be bred and raised in farms and would be released in nature to replenish the population. Experience will demonstrate the feasibility of using captive breeding as a tool to assist turtle conservation. In the present work the morphometry of commercially important freshwater turtle, Indian roofed turtle, Pangshura tecta was studied to ascertain the growth ratio per year in relation to body weight.

\section{MATERIAL AND METHODS}

The study was carried out at Matlab Bazar turtle market, Matlab upazila; Kaliatoli Bazar and Koiar-pool turtle market of Haziganj upazila, Chandpur sadar turtle market under Chandpur district; Baidder Bazar, Sonargoan upazila; Bot-toli, Jamtoli and Ghudara ghat under Narayanganj district; Mirpur section 10 and Ghudaraghat No 1, Tipu sultan Road, Sham Bazar and Kamalapur turtle export centre and Uttara Sector No. 14 turtle export processing centre under Dhaka district; Patkeel Bazar, Kadambari beel of Madaripur district; Zitka, Sebalaya, Gopinathpur of Manikganj district; and Moheshkhali and Kutubdia of Cox's Bazar district. The study was carried out between January 1997 and December 2000.

Morphometric analysis: A total of $125 P$. tecta $(\hat{0}=25$ and $q=100)$ were used for morphometric analysis. Curve carapace was measured from tip of nuchal shield to end of pygal and curve plastron width measured from middle of inframarginal shield left to right side. Straight plastron was measured from the tip of intergular to end of anal shield. The shell height was measured with taxonomic board in perpendicular way. For convenience of statistical analysis, the males and females were separated into weight groups for the study of frequency distribution. The relationship between the body weight and surface area of carapace and plastron was considered. The distribution of number and percentage of males and females were determined.

The length-weight relationship of turtle was determined by means of regression analysis using least square methods from the original data at confidence level 95\%. The regression co-efficient and correlation co-efficient were applied by means of ' $t$ '-statistic at $1 \%$ to $5 \%$ level of probability. The estimated weight was plotted against the corresponding length, width and shell height to obtain a linear curve distribution. Growth rate of various morphometric characters in relation to body weight of turtles was determined using the standard methods. For biometric study turtles were dissected and measured them on the basis of three categories, i.e. hard parts (carapace and plastron), soft parts (forelimbs, hindlimbs, neck, liver, heart and digestive tract) and other 
soft parts (blood, spleen and residue). Percentage of different organs in relation to body weight was also calculated by means of regression analysis.

Identification: The turtle is commonly known as 'Kori Kaitta'. The carapace is elevated, oval with a distinct vertebral keel that is spiked, especially on vertebra ' 111 '. First vertebral is as long as wide or longer than wide and vertebral 11 and 111 are variables. Vertebral ' $1 \mathrm{~V}$ ' is longer than wide and ' $\mathrm{V}$ ' is wider than long. Plastron is truncated anteriorly, notched posteriorly and snout is pointed. Carapace has brownish, red or orange stripe along the first three vertebral. Plastron is yellow or pink with 2 - 4 black markings on each plastral scute. Head is with reddish crescent shaped post- ocular markings, curving up from below the eyes to meet on the forehead. Neck with 32 longitudinal lines. Behind each eye or supercilium there is a kidney shaped purple color spot.

Sex determination: Male P. tecta was smaller in size compared to female, possessed a comparatively longer tail, with thick base. Male also possessed a white band on the top of the tail, while female possessed a yellow band.

Data analysis: The data were analyzed by relevant statistical methods. Regression analysis between two sexes was made to find out the relationship and difference in means of different parameters. The difference between sets of data for given parameters were subjected to analysis of variance (ANOVA). Computer package program Excel and SPSS (Version 10.00) were used for all the statistical analysis.

\section{RESULTS AND DISCUSSION}

The weight of males varied from 68 to $120 \mathrm{~g}$ (mean $92.6 \pm 13.3 \mathrm{~g}$ ) and females 175 to $985 \mathrm{~g}$ (mean $441.1 \pm 185.4 \mathrm{~g}$ ). The mean weight of females was 4.8 times higher than males on an average (Table 1). The surface area of carapace and plastron as well as the height of shell of males and females increased in relation to body weight. From the regression equation it is evident that the body weight and surface area of carapace and plastron of male P. tecta was strongly correlated $\left(\mathrm{y}=0.6215 \mathrm{x}+36.757, \mathrm{R}^{2}=0.9339\right.$ and $\mathrm{y}=0.1107 \mathrm{x}+$ $29.518, \mathrm{R}^{2}=0.8751$ ) and the regression lines were linearly fitted [Fig. 1a, b]. Whereas, the body weight and shell height was not so strong by correlated $(\mathrm{y}=$ $0.0032 x+1.1829, \mathrm{R}^{2}=0.4878$ ) and the regression line did not maintain linearity, which means the increase of body weight might not increase the shell height. The body weight and surface area of carapace and plastron of female $P$. tecta was strongly correlated $\left(\mathrm{y}=0.3266 \mathrm{x}+107.28, \mathrm{R}^{2}=0.9774\right.$ and $\mathrm{y}=$ $0.1912 \mathrm{x}+50.211, \mathrm{R}^{2}=0.9775$ ) and the regression lines were linearly fitted [Fig. $2 \mathrm{a}, \mathrm{b}]$. Whereas, the relationship between the body weight and shell height was not so strong by correlated $\left(y=0.0032 x+6.106, R^{2}=0.8618\right)$. 
Table 1. Morphometric measurements of P.tecta

\begin{tabular}{lcccc}
\hline \multirow{2}{*}{ Parameters } & \multicolumn{2}{c}{ Male $(\mathrm{n}=25)$} & \multicolumn{2}{c}{ Female $(\mathrm{n}=100)$} \\
\cline { 2 - 5 } & Range & Mean $\pm \mathrm{SD}$ & Range & Mean $\pm \mathrm{SD}$ \\
\hline Body Weight (BW) g & $68-120$ & $92.6 \pm 13.3$ & $175-985$ & $441.1 \pm 185.4$ \\
Curve Carapace Length (CCL) cm & $8.4-10.1$ & $8.9 \pm 0.5$ & $12.4-22.2$ & $16.2 \pm 2.2$ \\
Curve Carapace Width (CCW) cm & $9.2-11.1$ & $10.3 \pm 0.5$ & $12.1-20.1$ & $15.3 \pm 1.9$ \\
Straight Plastron Length (SPL) cm & $6.9-8.3$ & $7.6 \pm 0.4$ & $10.3-19.0$ & $14.0 \pm 2.0$ \\
Straight Plastron Width (S PW) cm & $4.9-5.4$ & $5.1 \pm 0.1$ & $6.8-12.5$ & $9.4 \pm 1.3$ \\
Straight Shell Height (SSH) cm & $1.3-1.7$ & $1.5 \pm 0.2$ & $5.7-8.8$ & $7.5 \pm 0.8$ \\
Surface area of carapace $\left(\mathrm{cm}^{2}\right)$ & $78.2-112.1$ & $92.3 \pm 9.7$ & $152-446.2$ & $251.3 \pm 64.8$ \\
Surface area of plastron $\left(\mathrm{cm}^{2}\right)$ & $35.3-43.2$ & $39.1 \pm 2.3$ & $71.3-238.5$ & $133 . \pm 36.1$ \\
\hline
\end{tabular}

Data relating to the various body measurements of $P$. tecta and the significance of correlation coefficient has been examined with the help of ' $t$ 'statistics (Table 2).

Table 2. The correlation co-efficient of body weight with length, width of carapace, plastron and shell height $P$. tecta

\begin{tabular}{lcc}
\hline Parameters & Correlation coefficient $(\mathrm{R})$ & $\begin{array}{c}\text { “ } t \text { '- statistic" } \\
\text { calculated value }\end{array}$ \\
\hline BW : CL o & 0.729 & $5.11^{* *}$ \\
BW : CL + & 0.972 & $39.48^{* *}$ \\
BW : CW o & 0.920 & $11.28^{* *}$ \\
BW : CW + & 0.943 & $27.35^{* *}$ \\
BW : PL o & 0.639 & $3.99^{* *}$ \\
BW : PL + & 0.957 & $3.92^{* *}$ \\
BW : PW o & 0.486 & $2.67^{* *}$ \\
CL : PL o & 0.369 & $3.98^{* *}$ \\
CL : PL + & 0.967 & $37.68^{* *}$ \\
BW : SH o & 0.496 & $2.68^{* *}$ \\
BW : SH + & 0.842 & $15.46^{* *}$ \\
\hline
\end{tabular}

Note: Body weight (BW), Carapace Length (CL), Carapace Width (CW), Plastron Length (PL), Plastron Width (PW), Shell Height (SH). **Significance at $1 \%$ level $(\mathrm{p}<0.01)$.

The percentage of biometric parameters, i.e. length and width of carapace, plastron and the shell height were estimated by the mean values of males and females. The body weight of males $P$. tecta was $17.4 \%$ whereas females was 82.6 $\%$. The length of carapace of males was $19.5 \%$ and females was $80.5 \%$. Carapace width of males was $40.2 \%$ and females was $59.8 \%$, plastron length of males was $35.3 \%$ and females was $64.7 \%$. Plastron width of males was $35.3 \%$ and females $64.7 \%$ and the shell height of males was $17.7 \%$ and females $83.3 \%$.

The reliability of the above equations would be seen to be high from the coefficient of correlation (R) values in all the cases. The data pertaining to correlation co-efficient of body weight and carapace, plastron and the shell 
height of both males and females in Table 2 furnish an idea that the characteristics are highly correlated and their values are significant.
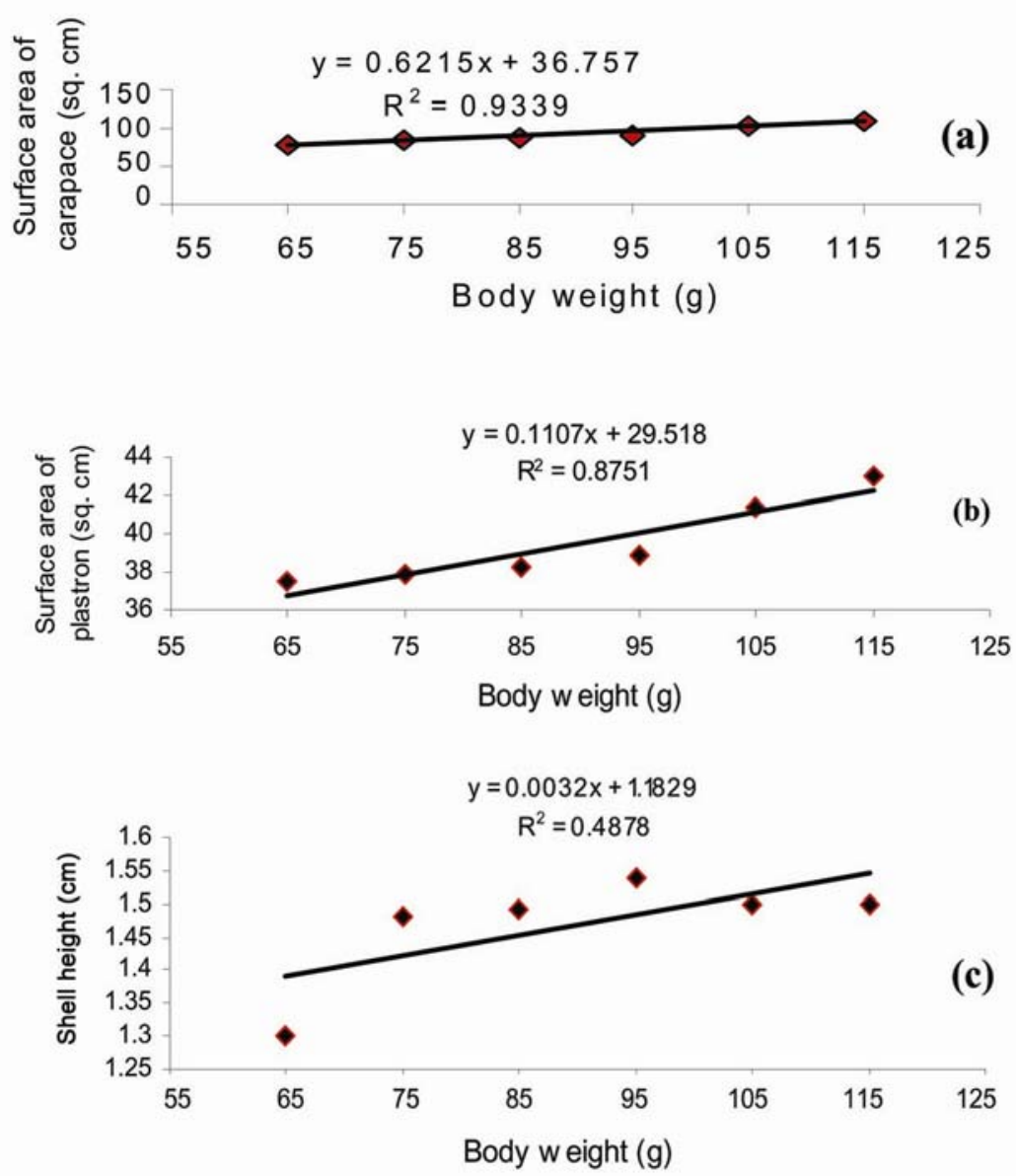

.Fig. 1. Regression lines of male P. tecta: (a) Surface area of carapace on body weight (b) Surface area of plastron on body weight (c) Shell height on body weight

Biometric analysis of $P$. tecta showed that the weight of turtles varied from 565 to $700 \mathrm{~g}$ (mean $623.3 \pm 36.5 \mathrm{~g}$ ). The hard parts varied from 200 to $283 \mathrm{~g}$ (mean $223 \pm 22.9 \mathrm{~g}$ and soft parts 365 to $450 \mathrm{~g}$ (mean $400 \pm 24.9 \mathrm{~g}$ ). The percentage of hard parts was $35.8 \pm 2.5 \%$ and soft parts $64.2 \pm 2.5 \%$ (Table 3 ). The relation between hard parts and soft parts was correlated and statistically significant $(\mathrm{R}=0.61, \mathrm{n}=12, \mathrm{t}=2.67$ and, $\mathrm{p}<0.05)$. Of the hard parts, the carapace weight was $(70.4 \%)$ it was always 2.4 times higher than weight of plastron $(29.6 \%)$, and the ratio was $7: 3$. Of the soft parts, the weight of digestive tract was the highest of all other soft parts of the turtles (Table 3). 


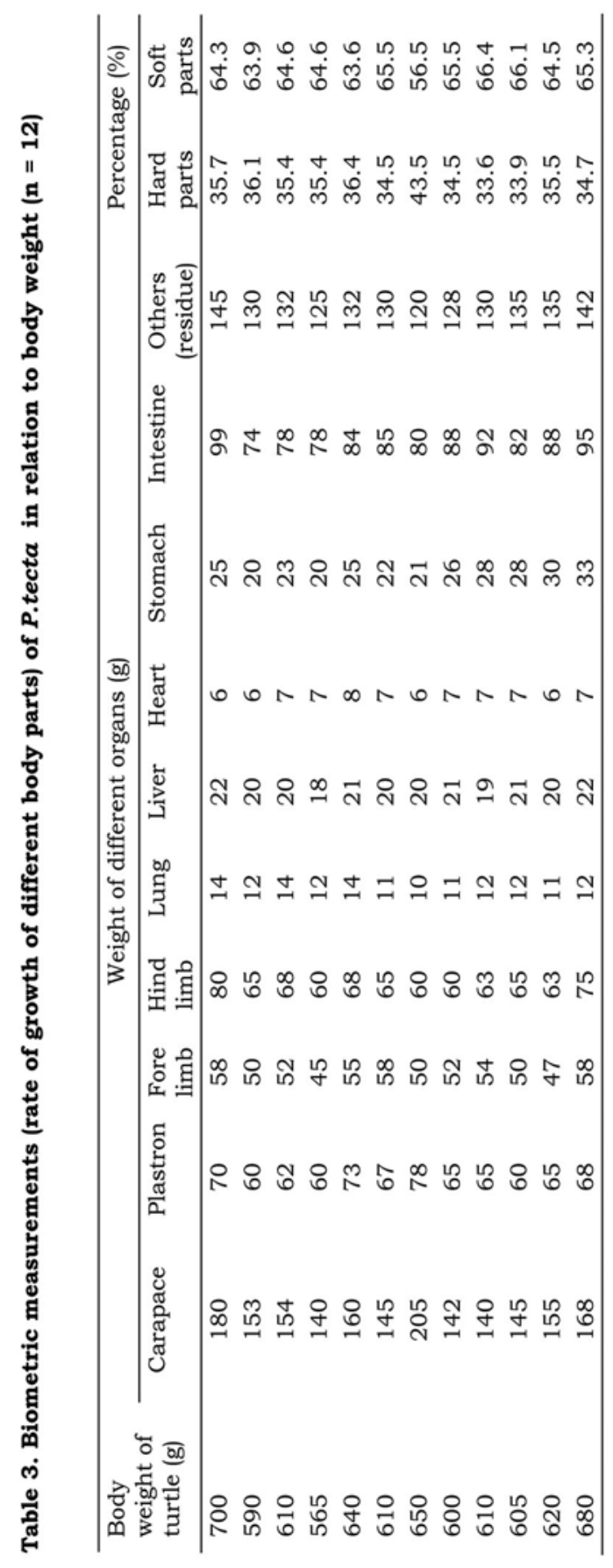



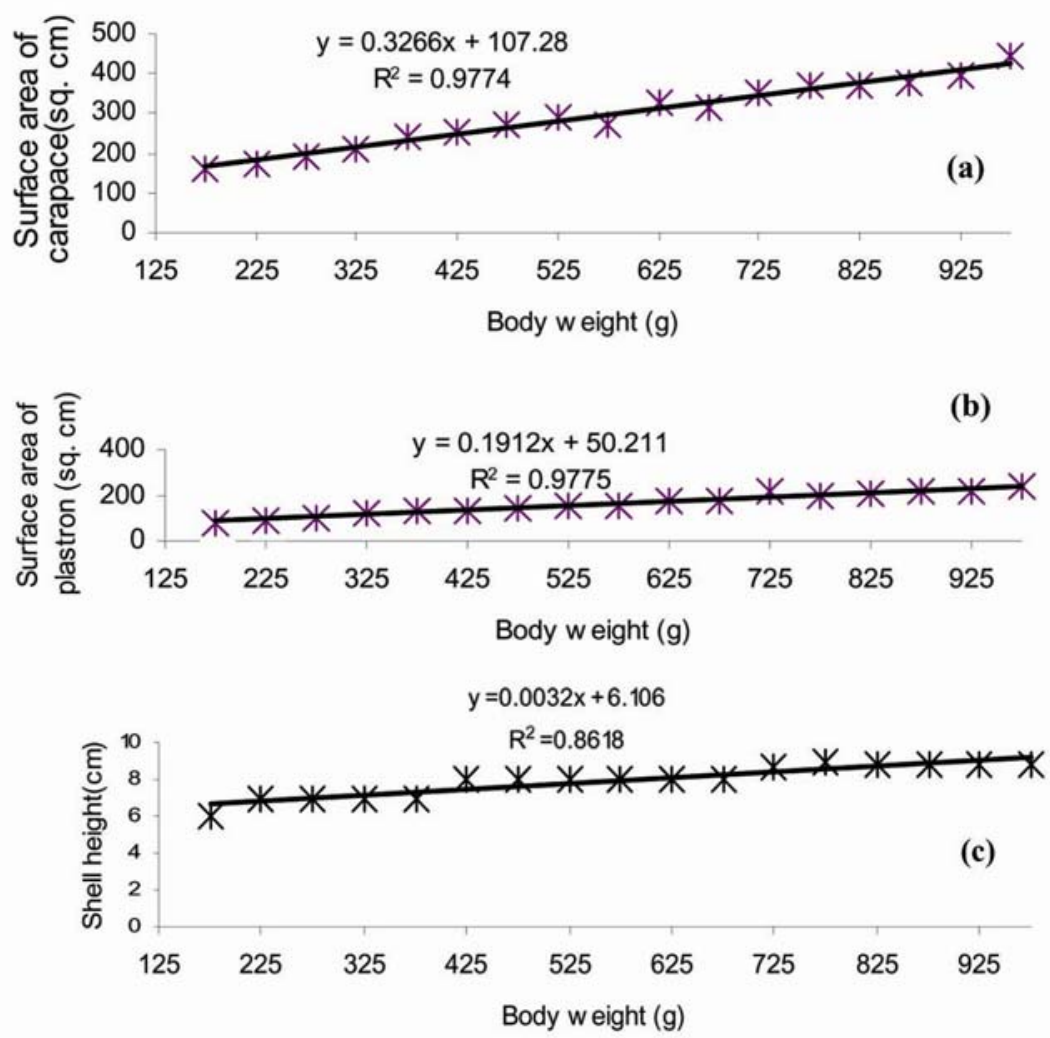

Fig. 2. Regression lines of female $P$. tecta: (a) Surface area of carapace on body weight (b) Surface area of plastron on body weight (c) Shell height on body weight

It was found that the maximum Curve Carapace Length (CCL) of male $P$. tecta was $10.1 \mathrm{~cm}$ and that of female $22.2 \mathrm{~cm}$; Curve Carapace Weight $(\mathrm{CCW})$ of male was $11.1 \mathrm{~cm}$ and that of female $20.1 \mathrm{~cm}$; PL of male $8.3 \mathrm{~cm}$ and that of female $19 \mathrm{~cm}$ and the $\mathrm{SH}$ of male was $1.7 \mathrm{~cm}$ and that of female $8.8 \mathrm{~cm}$. The maximum weight of male was $120 \mathrm{~g}$ and that of female $985 \mathrm{~g}$. Smith (1931) and Das (1995) observed that the maximum carapace length of $P$. tecta was $23.0 \mathrm{~cm}$ where the sex and weight were not mentioned. Minton (1966) mentioned that the male was $17.0 \mathrm{~cm}$ and its SH $10.5 \mathrm{~cm}$. Whereas, Moll (1987) stated that CL of large male was $6.6 \mathrm{~cm}$, CW $5.4 \mathrm{~cm}$, PL $6.1 \mathrm{~cm}$, PW $4.1 \mathrm{~cm}$ and the SH was 3.7 $\mathrm{cm}$, and BW $540 \mathrm{~g}(\mathrm{n}=7)$, the author also added that $\mathrm{CL}$ of adult female was $15.3 \mathrm{~cm}$, CW $11.5 \mathrm{~cm}$, PL $14.7 \mathrm{~cm}$, SH $7.3 \mathrm{~cm}$, and BW $510 \mathrm{~g}$, other female had the CL $18.3 \mathrm{~cm}$, CW $14.2 \mathrm{~cm}$, PL $17.2 \mathrm{~cm}$, SH $5.4 \mathrm{~cm}$, and BW 960g. Frazier (1997) reported that CCL was $10.7 \mathrm{~cm}$, SCL $9.3 \mathrm{~cm}, \mathrm{CW} 12.1 \mathrm{~cm}, \mathrm{SH} 4.6 \mathrm{~cm}$ and BW was $110 \mathrm{~g}$ without mentioning the sex. Das (1991) concluded that the female $P$. tecta attained maturity at the length $23.0 \mathrm{~cm}$, weight $600 \mathrm{~g}$. The present study 
showed that the female attained maturity at the carapace length of $18.2 \mathrm{~cm}$ and body weight of $482 \mathrm{~g}$. Shrestha (1997) mentioned that the turtle reaches about $230 \mathrm{~mm}$ in length. Minton (1966) mentioned from Pakistan, CL of female was between $16.4 \mathrm{~cm}$ and $17.3 \mathrm{~cm}, \mathrm{CW} 14.7 \mathrm{~cm}$ and $15.3 \mathrm{~cm}$, PL $11.5 \mathrm{~cm}$ and 11.7 $\mathrm{cm}$, SH $7.3 \mathrm{~cm}$ and $8.4 \mathrm{~cm}$. when BW was $510 \mathrm{~g}$, and the CL of male 6.6, CW 5.4 , PL $6.3 \mathrm{~cm}$, SH $3.7 \mathrm{~cm}$ and BW $54 \mathrm{~g}$. These differences might have happened due to different habitat and study period and the abundance in the field.

The present study revealed that the females were 4.8 times larger than males. In addition, males differ from females by having a longer and thicker tail that opens beyond the carapace rim as was also reported by Moll (1987), Iverson (1992), Das (1995) and Rashid and Swingland, (1997). The female was significantly longer than male, similar observation was made by Shrestha (1997).

\section{LITERATURE CITED}

BARUA, G. and ISLAM, M.A. 1986. Status of the edible Chelonian export from Bangladesh. Bangladesh J. of Fish. 9(1-2): 33 - 38.

BOULENGER, G.A. 1890. The Fauna of British India including Ceylon and Burma, Reptilia and Batrachia, Tailor and Franchis, London, 541 pp.

CHAUDHURY, B.L. 1912. Aquatic Tortoises of the middle Ganges and Brahmaputra, Rec. Indian Mus. (Calcutta) 7: 212 - 214.

COLLINS 1990. Asian Turtles are threatened by extinction. Turtle and Tortoises Newsletter, 1 : 7 -11. DAS, I. 1991. The export of freshwater turtles from Bangladesh. Oryx., 24 : 163 - 166.

DAS, I. 1995. Turtles and Tortoise of India. Oxford University Press, Bombay, 176+x pp.

FRAZIER, N.B. 1997. Turtle Conservation and Halfway Technology. Proc. Conservation, Restoration and Management of Tortoises and Turtles, USA. pp. $422-425$.

FUGLER, C.M. 1984. The commercially exploited Chelonia of Bangladesh. Taxonomy, Ecology, Reproductive biology and Ontogeny. Bangladesh Fish. Int. Bull., 2 (1) : 01- 52.

GUPTA, V.K. 1987. Retention of eggs by the Emydine turtles, Kachuga tecta and K. smithi. J. Bombay Nat. Hist. Soc., Bombay. 84(2): 445 - 446.

HOSSAIN, M.L. 2000. Wildlife in wetlands. A Mission Report on the status of wildlife in the floodplain areas, Bangladesh. For IUCN - Bangladesh Country office, Dhanmondi, Dhaka, Bangladesh.140 pp.

HOSSAIN, M.L. and SARKER, S.U. 1993. Freshwater turtles of Bangladesh. Bangla Academy Biggan Patrica, Dhaka. 20(1) : 109-120.

HOSSAIN, M.L. and SARKER, S.U. 1995a. Reproductive biology of Indian roofed turtle, Kachuga tecta in Bangladesh. J. Chelonian Conservation and Biology. Int. Bull. Chelonian Research, Lunenburg, USA. 1(3) : 226-227.

HOSSAIN, M.L. and SARKER, S.U. 1995b. Ecology and food habit of Indian Roofed Turtle, Kachuga tecta in Bangladesh. Dhaka Univ., J. Biol. Sci., Dhaka. 4(1): 19-24.

KHAN, M.A.R. 1980. The Holy Turtle of Bangladesh. Hornbill. 4 : 7 - 11.

KHAN, M. A. R. 1982. Wildlife of Bangladesh. A Checklist. University of Dhaka. Print at City press, Dhaka, $174 \mathrm{pp}$.

KHAN, M.A.R. 1987. Wildlife of Bangladesh. Part 2. Bangla Academy, Dhaka. pp 175. 
MICHAEL, W.N. and GRAY, A. 2000.Wildlife trade in southern China including Hongkong and Macao. Internet. $17 \mathrm{pp}$.

MINTON, S.A. 1966. A contribution to the Herpetology of West Pakistan. Bull. Amer. Mus. Nat. Hist. $134: 27-184$.

MOLL, E.O. 1987. Survey of the freshwater turtles of India part 11. The genus Kachuga J. Bombay Nat. Hist. Soc. Bombay. 84 (1): 7-25.

PHILIP, G., MORAL, S. and RAJ, P. 1998. Bangladesh environment facing 21st century. Society for Environment and Human Development pp. $308+$ viii.

RAO, R.J. and SINGH, L.A.K. 1987. Notes on the ecological relationship in basking and nesting site utilization among Kachuga spp. (Reptilia: Chelonia) in National Sambal Sanctuary. J. Bombay Nat. Hist. Soc., Bombay. 84(3): 599 - 604.

RAO, R.J. and SINGH, L.A.K. 1990. Notes on comparative body size, Reproductive effort and areas of management priority for three species of Kachuga (Reptilia, Chelonia) in the national Chambal Sanctuary J. Bombay Nat. Hist. Soc., Bombay. 84 (1) : 55-65.

RASHID, S.M.A. 1991. On the occurrence of Indian Roofed Turtle, Kachuga tecta in saline water in southern Bangladesh. British Herpt. Bull. pp. 36-39.

RASHID, SM.A. and SWINGLAND, I.R. 1997. On the ecology of some freshwater turtles in Bangladesh Proc. Conservation Restoration and Management of tortoise and turtles. An Int. Conf. Turtle and Tortoise Society, pp. 225-242.

RASHID, S.M.A. and KHAN, S.M.M.H. 2000. Trade and conservation status of freshwater turtles and tortoises in Bangladesh. Asian Turtle Trade. Chelonian Res. Monographs, 2: 77 - 85.

RHODIN, A.G.J. 2001. The Asian Turtle Crisis. Chelonian Research Foundation, New York $01-02$ pp.

SANDRA, A. and DANIELA, F. 2000. Asian turtles are threatened by extinction. Turtle and Tortoise. Newsletter, (The Newsletter of Chelonian Conservationists and Biologists), By Chelonian Res. Foundation, $1: 1$ - 9.

SARKER, S.U. and HOSSAIN, M.L. 1997. Population and habitat status of freshwater turtles and tortoises of Bangladesh and their conservation aspect. Proc. Conservation, Restoration, and Management. USA. pp. 290-294.

SHAFI, M. and QUDDUS, M.M.A. 1987. Bangladesher Matsha Sampad. Bangla Academy, Dhaka.

SHRESTHA, T.K. 1997. Status, Biology, Conservation and Management of Tortoises and Turtles in the Himalayan Foothills of Nepal, Proc. Conservation, Restoration, and Management of Tortoises and Turtles, Lunenburg, USA. pp. 278-286.

SMITH, M.A. 1931. The Fauna of British India including Ceylon and Burma; Reptilia and Amphibia, Taylor and Franchis London. Vol.1. pp. $179+$ xxvi.

VOGT, R.C. and BENITEZ, J.V. 1997. Species abundance and biomass distribution in freshwater turtles. Proc. Conservation, Restoration and Management of Tortoises and Turtles, Lunenburg, USA. pp. 210-218.

WHITAKER, R. and ANDREWS, H.V. 1997. Captive Breeding of Indian Turtles and Tortoises at the center for Herpetology, Madras Crocodile Bank. Proc. Conservation Management of Tortoises and Turtles. An Int. Conf. New York Turtle and Tortoise Soc., pp. 166 -170. 